ISSN $0719-210 X$

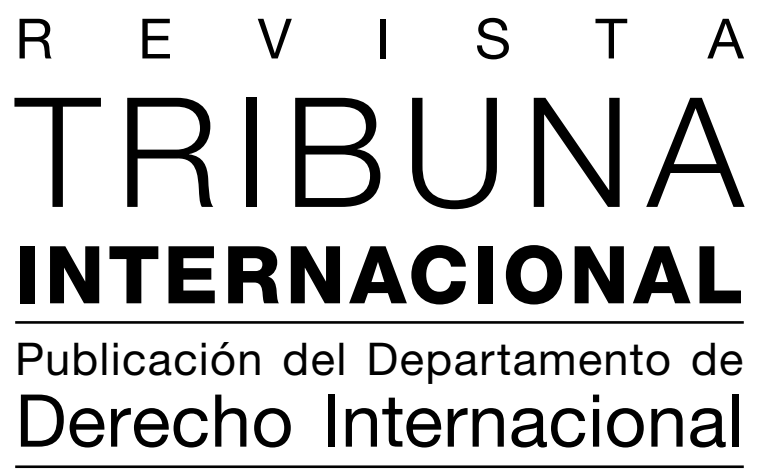

Volumen $2 / \mathrm{N}^{\circ} 3 / 2013$

FACULTAD DE

DERECHO 


\section{Rector de la Universidad de Chile}

Víctor Pérez Vera

Av. Alameda Libertador Bernardo

O'Higgins 1058, Santiago

\section{Representante legal}

Roberto Nahum Anuch

Decano de la Facultad de Derecho de la Universidad de Chile

\section{Director Responsable}

Mario Ramírez Necochea

\section{Editoras de Contenidos}

Rita Lages

Claudia Sarmiento Ramírez

\section{Comité Editorial}

Gonzalo Aguilar

José Carlos Fernández Rosas

Claudio Grossman

Mattias Kumm

Hugo Llanos

Cecilia Medina

Elina Mereminskaya

Mónica Pinto

\section{Comité de Árbitros}

Sergio Alburquenque Lillo (Chile)

Paulina Astroza (Chile)

Carolina Belmar (Chile)

María Paz Canales (Chile)

Alberto Coddou (Chile)

Zoya Galarza (Bolivia)

Nadia Franco-Bazán Ó Laighín (Panamá)

Rodrigo Lledó Vásquez (Chile)

Andrea Lucas Garín (Argentina)

Ignacio Mujica Torres (Chile)

Gloria Ramos Fuentes (Chile)

Marcela Ruiz Calderón (Chile)

Christian Sommer (Argentina)

Carolina Stefoni (Chile)

Gustavo Tocopillán (Argentina)

Miguel Torres (Cuba)

Cecilia Urbina (Chile)

Gustavo Luiz Von Bahten (Brasil)

\section{Revista Tribuna Internacional}

Publicación del Departamento de Derecho Internacional de la Facultad de Derecho de la Universidad de Chile Volumen 2 / No 3 / 2013 www.tribunainternacional.uchile.cl ISSN: 0719-210X

\section{Diseño y producción:}

Productora Gráfica Andros Ltda. www.androsimpresores.cl

Impreso en Chile/ Printed in Chile 


\section{ÍNDICE}

\section{Artículos}

Matrimonios entre personas del mismo sexo celebrados en el extranjero y sus efectos jurídicos en Chile. Análisis crítico del artículo 80 de la Ley de Matrimonio Civil

Pablo Andrés Cornejo Aguilera

La responsabilidad en el derecho penal internacional: una aproximación

desde la filosofía de John Searle. Reflexiones a partir del caso Lubanga

Rodrigo A. González Fernández y M. Soledad Krause Muñoz

Effectiveness of REDD programs in the protection of suigeneris

indigenous rights

Paloma Infante $M$.

Los usos. Si las inversiones y operaciones comerciales en diversos sectores

implican diversos riesgos y oportunidades, ¿por qué no se invocan

adecuadamente "los usos" en el procedimiento arbitral?

Hernany Veytia

\section{Comentarios de jurisprudencia}

La Orden de Medidas Provisionales del Tribunal Internacional del

Derecho del Mar en el caso del buque de guerra ARA Libertad

Martín Cabrera Mirassou

A Case of Equitable Maritime Delimitation: Nicaragua and Colombia in the Western Caribbean Sea

Paul S. Reichler 


\section{Recensiones}

"Guerra de las Malvinas. Noticia en desarrollo 1982-2012"

(Editorial El Mercurio, Santiago, 2012), de José Rodríguez Elizondo, por Juan Emilio Cheyre

"La Convención sobre Derechos del niño. Instrumento de progresividad en el Derecho Internacional de los Derechos Humanos"

(Editorial Dykinson, Madrid, 2011), de María del Rosario Carmona Luque, por Lucía Rizik Mulet 


\title{
Effectiveness of REDD programs in the protection of sui generis indigenous rights ${ }^{1}$
}

La efectividad de los programas REDD en la protección de los derechos indigenas sui generis

\section{Paloma Infante $M$.}

palomaim@yahoo.com

Abogada de la Universidad de Chile y Magíster en Derecho Ambiental de la Universidad de Nueva York. Ayudante de la cátedra de Derecho Ambiental de la Facultad de Derecho de la Universidad de Chile y profesora del Curso Bases del Derecho Ambiental de la Universidad del Desarrollo. Actualmente trabaja en la Superintendencia del Medio Ambiente y es colaboradora del Vance Center for International Justice del Colegio de Abogados de Nueva York. Miembro de la Comisión de Medio Ambiente del Colegio de Abogados de Chile.

\begin{abstract}
The article focuses on the implementation of the United Nations Reducing Emission from Deforestation and Forest Degradation Program, hereinafter UN REDD and its effectiveness in the protection of sui generis indigenous rights, meaning those different from the property right but derived from it, especially, the rights over the territories, natural resources and environmental services.

The paper will cover the interconnection between sui generis indigenous rights and REDD programs including the relevance of land tenure and the sui generis rights derived from it. As we will emphasize, REDD programs are not only focused in the reduction of carbon emissions. In fact, REDD plus programs include as a main objective the sustainable management of forests and the protection to forest dependent communities.
\end{abstract}

Keywords: indigenous rights, sui generis rights, property right, Reducing Emissions from Reforestation and Forest Degradation Program, REDD/REDD plus, United Nations.

Resumen: Este articulo se enfoca en la implementación del Programa de Reducción de Emisiones derivadas de la Reforestación y la Degradación Forestal de la Organización de Naciones Unidas, en adelante REDD, y su efectividad en la protección de derechos indigenas sui generis, entendidos tales como aquellos distintos del derecho de propiedad, pero derivados de este; en especial, los derechos indígenas sobre el territorio, los recursos naturales y los servicios ambientales que prestan los ecosistemas.

1 Fecha de recepción: 14.03.2013 y fecha de aceptación: 19.04.2013. 
El articulo revisa la interconexión que existe entre los derechos indigenas sui generis $y$ los programas REDD, incluyendo la relevancia de la tenencia de las tierras y los derechos sui generis derivados de esta. Como enfatizaremos, los programas REDD no solo están enfocados en la reducción de las emisiones; de hecho, el programa REDD plus incluye, dentro de sus principales objetivos, el manejo sustentable de los bosques y la protección de aquellas comunidades que dependen de estos.

Palabras clave: derechos indígenas, derechos sui generis, derecho de propiedad, Programa de Reducción de Emisiones derivadas de la Reforestación y la Degradación Forestal, REDD/ REDD plus, Organización de Naciones Unidas.

\section{Introduction}

This paper focuses on the implementation of the United Nations Reducing Emission from Deforestation and Forest Degradation Program, hereinafter UN REDD, and it effectiveness in the protection of sui generis indigenous rights, meaning those different from the property right but derived from it, specially, the rights over the territories, natural resources and environmental services.

This work analyse the mechanism of REDD in order to create the right incentives for indigenous communities as main stakeholders of the Program. In this context, the paper discuss the implications of indigenous peoples rights over REDD plus benefits, and how the implementation of REDD and the level of recognition of indigenous rights, including the sui generis rights, could influence the successful of REDD. In other words, how the recognition and incorporation of these sui generis rights in the implementation of REDD programs is a key factor for REDD to achieve it commitment. The paper will try to demonstrate that the content of these rights is so special and unique that it is essential for REDD to take them into account in order to assure the success of the program.

One of the key discussions around the REDD effects is connected with those that will be generated to indigenous communities, as the main users of the forests. The paper analyse if the special features of indigenous rights in general could influence REDD effectiveness. Section 2 offers a general description of REDD and REDD plus concepts, the international participation and the main benefits and criticism that REDD initiatives have received in relation with the indigenous rights. In section 3, the paper reviews the 
key concepts associated to REDD, REDD plus and the UN REDD initiative. In addition, and in order to understand the relevant indigenous concerns, this section also lists the main benefits and criticisms made to REDD.

Section 4 of the research includes the analysis of the particular sui generis indigenous rights and the way in which are generally recognized. Finally, the paper will cover the interconnection between sui generis indigenous rights and REDD programs including the relevance of land tenure and the sui generis rights derived from it. As we will emphasize, REDD programs are not only focused in the reduction of carbon emissions. In fact, REDD plus programs include as a main objective the sustainable management of forests and the protection to forest dependent communities.

\section{Un REDD Program}

(i) REDD and REDD plus (or REDD+) concepts

The United Nations defines REDD as "a mechanism to create an incentive for developing countries to protect, better manage and wisely use their forest resources, contributing to the global fight against climate change. REDD strategies aim to make forests more valuable standing than they would be cut down, by creating a financial value for the carbon stored in trees. Once this carbon is assessed and quantified, the final phase of REDD involves developed countries paying developing countries carbon offsets for their standing forests. REDD is a cutting-edge forestry initiative that aims at tipping the economic balance in favour of sustainable management of forests so that their formidable economic, environmental and social goods and services benefit countries, communities, biodiversity and forest users while also contributing to important reductions in greenhouse gas emissions"2.

In other words, REDD is a financial mechanism designed to reduce greenhouse gasses emissions produced by the deforestation and forest degradation through market inducements.

2 UN-REDD Programme, Section about REDD+, available at www.un-redd.org. 
In addition, REDD plus includes concepts as sustainability, public participation, enhancement of forest carbon stocks and protection of the local and indigenous communities rights. To foment the REDD plus goals, the Cancun Agreements ${ }^{3}$ listed the following five recognized activities related to the REDD plus concept:

(a) Reducing emissions from deforestation;

(b) Reducing emissions from forest degradation;

(c) Conservation of forest carbon stocks;

(d) Sustainable management of forest; and

(e) Enhancement of forest carbon stocks ${ }^{4}$.

Also, the Cancun Agreements establish the stages through which REDD programs will be implemented. As explained by the World Resources Institute ${ }^{5}$, the Cancun Agreements provide countries with guidance on REDD+ readiness. This should include a national plan, a national reference emission level, a robust and transparent national forest monitoring system, and a system for providing information for how Safeguards -such as respecting indigenous peoples' rights- are being addressed and respected.

Furthermore, Annex 1 of the Agreements provide more details about the principles and Safeguards that stakeholders undertaking activities and providing finance will need to respect, even in the "fast-start" finance period. In literal words, while the language in the text could have been stronger, it represents a significant shift in the type of language included in UNFCCC documents to date and is one of the most significant aspects of the text.

Through global activities, UN-REDD Program work is divided in the following seven work areas: (i) Measurement, reporting and verification (MRV) and monitoring, (ii) Engagement of Indigenous Peoples, civil society and other stakeholders,

3 The Cancun Agreements are a set of significant decisions by the international community to address the long-term challenge of climate change collectively and comprehensively over time and to take concrete action now to speed up the global response. More information available at http://cancun.unfccc.int/.

4 Cancun Agreements. Article 70 of paragraph III. Enhanced action on mitigation, section C. Policy approaches and positive incentives on issues relating to reducing emissions from deforestation and forest degradation in developing countries; and the role of conservation, sustainable management of forests and enhancement of forest carbon stocks in developing countries of the Cancun Agreements.

5 Austin, Kemen; Daviet, Florence and Stolle, Fred. The REDD+ Decision in Cancun, December 2010, available at http://www.wri.org/stories/2010/12/redd-decision-cancun. 
(iii) Multiple benefits, (iv) Knowledge management, coordination and communication, (v) National REDD+ governance, (vi) Equitable benefit sharing systems and (vii) Sectorial transformation.

\section{(ii) Origin of REDD}

REDD programs have been developed as a responses to climate change. In 1997, the Kyoto Protocol did not contemplate regulations and policies related to deforestation and forest due to the complexity of measurements and monitoring derived from these activities. Later, the Agreement of the 15th Conference of the Parties (COP-15) to the United Nations Framework Convention of Climate Change, UNFCCC, included a statement related to the management of the forests, without detailed compromises or obligations. Finally, in the $16^{\text {th }}$ Conference of the Parties, COP-16 the Cancun Agreements included specific provisions related to REDD and the concept of REDD plus ${ }^{6}$. In this context, the UN has established a collaborative initiative to develop the REDD and REDD plus implementation within developing countries ${ }^{7}$.

6 The Cancun Agreement (Section I Para 10) adopted by the COP to the UNFCCC in December 2010 states that "addressing climate change requires a paradigm shift towards building a low-carbon society that offers substantial opportunities and ensures continued high growth and sustainable development, based on innovative technologies and more sustainable production and consumption and lifestyles, while ensuring a just transition of the workforce that creates decent work and quality jobs".

7 According to the web page of the UN REDD program (http://www.un-redd.org/AboutUNREDDProgramme/ tabid/583/Default.aspx): "The UN Program currently has 35 partner countries spanning Africa, Asia-Pacific and Latin America, of which 14 are receiving support to National Programme activities. These 14 countries are: Bolivia, Cambodia, Democratic Republic of the Congo (DRC), Ecuador, Indonesia, Nigeria, Panama, Papua New Guinea, Paraguay, the Philippines, Solomon Islands, Tanzania, Viet Nam and Zambia. To-date, the UN-REDD Programme's Policy Board has approved a total of US\$59.3 million for National Programmes in these 14 partner countries. These funds help to support the development and implementation of national REDD+ strategies.

UN-REDD Programme countries not receiving direct support to national programmes engage with the Programme in a number of ways, including as observers to the Programme's Policy Board, and through participation in regional workshops and knowledge sharing, facilitated by the Programme's interactive online workspace are: Argentina, Bangladesh, Bhutan, Central African Republic, Colombia, Costa Rica, Ethiopia, Gabon, Guatemala, Guyana, Honduras, Ivory Coast, Kenya, Mexico, Mongolia, Nepal, Pakistan, Peru, Republic of Congo, Sri Lanka and Sudan”. 
(iii) International participation

According to the information provided by the UN REDD program, REDD mechanisms have been well received by some national governments. The Norwegian government for example has provided $\$ 500$ million towards the creation and implementation of nationalbased REDD activities in the nation of Tanzania. United Kingdom also contributed with $\$ 200$ million towards the Congo Basin Forest Fund to aid forest conservation actives in Central Africa.

Australia has also joined the efforts to promote REDD mechanisms with a $\$ 200$ million International Forest Carbon Initiative focused on developing REDD activities in areas like Indonesia, and Papua New Guinea. The governments of Spain and Denmark have recently become donors to the UN REDD Program too.

The UN REDD has commenced pilot programs to progressively implement the guidelines of REDD and REDD plus. The DRC and Bolivia are part of those pilot programs ${ }^{8}$. According to the UN-REDD Programme Policy Brief document, prepared for the Durban Conference, "even though there is not yet compliance demand for REDD+, pilot projects are selling carbon credits through the voluntary sector using approaches such as those developed by the Verified Carbon Standard and the Climate Community and Biodiversity Alliance. A number of pilot projects are being developed in countries like Brazil, Cambodia, Cameroon, China, Ecuador, Tanzania, Viet Nam to name a few. In Indonesia alone, there are more than 100 projects being developed at different scales"?.

8 The Countries receiving direct support to UN REDD Programme are: (i) Bolivia, (ii) Cambodia, (iii) Democratic Republic of the Congo, (iv) Ecuador, (v) Indonesia, (vi) Nigeria, (vii) Panama, (viii) Papua New Guinea, (ix) Paraguay, (x) The Philippines, (xi) Solomon Islands, (xii) Tanzania, (xiii) Viet Nam and (xiv) Zambia. In addition to the $14 \mathrm{UN}$-REDD Programme countries receiving support to National Programmes, the Programme also supports 21 other partner countries across Africa, Asia-Pacific and Latin America. These countries are: Argentina, Bangladesh, Bhutan, Central African Republic, Colombia, Costa Rica, Ethiopia, Gabon, Guatemala, Guyana, Honduras, Ivory Coast, Kenya, Mexico, Mongolia, Nepal, Pakistan, Peru, Republic of Congo, Sri Lanka and Sudan. These countries have access to many benefits of the Programme, such as networking, participation in regional workshops and knowledge sharing, as well as observer status to the UN-REDD Programme Policy Board. As the Programme mobilizes more resources, these partner countries will be given the opportunity to present National Programmes to the UN-REDD Programme Policy Board for funding, based on criteria that are currently being developed (http://www.un-redd.org/).

9 Sukhdevb, Pavan; Prabhua, Ravi; Kumara, Pushpam; Bassic, Andrea; Patwa-Shaha, Wahida; Entersa, Thomas; Labbatea, Gabriel and Greenwalta, Julie. REDD+ and a Green Economy: Opportunities for a mutually supportive relationship, November 2011, available at http://www.un-redd.org/. 


\section{(iv) Main benefits and criticisms of REDD}

REDD has not been a peaceful concept among the governments, local communities and NGOs. A number of criticisms have arrived against the concept in a wide range of areas. On the other hand, REDD has been associated with a list of benefits, environmental, social and economic.

It is necessary to bear in mind that REDD is a relatively new concept and empirical experience is not enough yet to do a final sentence about the effectiveness of the program. However, below is a list with the main criticisms and benefits that have arose in connection with REDD, especially in relation with indigenous communities:

\section{(iv.1) Main Benefits:}

- In connection with the social benefits associated to REDD and REDD plus, the projects will enhance the participation and empowerment of local communities (mostly but not exclusively, those which are forest dependents). In addition, REDD programs will strength the governance by constructing organizational structures in local-basis mechanisms.

- Also, generally poor communities will directly receive the benefits of the carbon reduction. Thus, REDD will create direct financial incentives through the sustainable use of forests.

- The production process of certain products derived from forests will be fomented.

- REDD will improve the development of a green economy. As explained by the UN REDD Programme Policy Brief document, some of the direct benefits related to the a green economy based on carbon emission reductions from deforestation and forest degradation will be: (i) the investment in ecologically-friendly agriculture, (ii) the creation of jobs related to ecosystem services, (iii) land tenure clarification, (iv) enhanced participation in decision-making under stronger governance (v) the reduction of pressure on natural forests, (vi) the improvement of freshwater and waterway management to support plantations and (vii) Better land-use and spatial planning and management, recognizing the importance of ecosystem services and biodiversity conservation and what they deliver ${ }^{10}$.

10 Ibidem. 
- Finally, and indirectly related to the improvement of indigenous lives, REDD programs were originally and primary conceived to reduce greenhouses emissions from forest degradation and deforestation and the protection of valuable ecosystems.

\section{(iv.2) Main Criticisms:}

- REDD will have impacts on local and indigenous communities due to the implementation of financial mechanisms that could generate disputes inside the communities and outside too if the land tenure rights are not well established.

- REDD promotes the commercialization of natural resources, and the purchase of the so-called "permits to pollute". Putting a commercial value on forests mistreat the transcendent (and religious in some cases) value woodlands hold for indigenous peoples.

- In most of the cases, the forest dependent communities do not have real participation in the decision-making processes of the States. This could be caused by the lack of recognition of their participatory rights and/or by the unstable organization that indigenous communities sometimes have.

- Land tenure and use of natural resources by the indigenous peoples are not clearly recognized by the legal systems. Thus, the implementation of REDD programs could generate conflicts among the communities, project developers and /or the governments. In addition, when the rights over natural resources and lands are not included as part of the customary rights of the communities, the conflict could arise also among it members.

- There are difficulties in the REDD implementation mainly due to the structure of funding mechanisms and the equitable distribution of benefits.

- In an indirect way, REDD could affect the indigenous communities due to the following additional reproaches: (i) REDD promotes the entry of massive transnational corporations in developing countries which only objective is the use of natural resources. The argument here is made base upon the fact that upcoming regulations and incentives of REDD could motivate countries to accelerate the logging process (mostly in an informal way) in order to get a major gap and therefore receive more revenues for further conservation. ii) Developing countries are not prepared to implement REDD because the government structure in these countries is not strong enough and thus there are not enforcement mechanisms to control the fulfillment of the deforestation's prevention, (iii) REDD foments the collusion among states based on the final purpose to have financial benefits from the carbon credits sales, 
(iv) REDD programs could have leakage problems and (vi) regarding to technical concerns, is very difficult to measure and set the baselines of forest reductions and emissions in order to mitigate.

- Also, REDD can undermine the traditional use of the forests by forest dependent communities. These multiple uses include socio-economic, cultural and spiritual benefits, the use of no-timber related resources (soil, water, seeds and fruits) along with the conservation and sustainable use of biological diversity. The main criticism here is that REDD programs could prevent indigenous of the use of their forests or impose burdensome restrictions on this.

- Finally, REDD initiatives have been criticized due to the "perverse incentives" that the payment of emissions reductions could produce on the forest users. These perverse incentives include the expulsion of indigenous peoples from their own lands if the land tenure and rights over the resources are not well established.

As we may deduct, a large number of critiques are related to the way in which indigenous communities could be affected if their rights over the land and forest resources are insecure. Therefore, in the next section we will analyze the significance of the indigenous rights in a classic view (land tenure, resources-use rights, participatory rights, etc.) and the we will describe the sui generis rights derived from them (rights over the territories, natural resources and environmental services) in order to confirm that the key for the REDD effectiveness is based on the incentives that states and international actors could give to whom are the effective guardians of the forests.

\section{(v) Legal/policy requirements concerning indigenous people}

As explained above, the requirements related to the protection of indigenous peoples and the enhancement of sustainable projects as a whole were incorporated in the concept of REDD plus. Indigenous peoples and peasants are in most of the cases the natural users of forests and one of the main concerns around REDD is precisely how the implementation of these programs could affect the life style of this people. The International Indigenous Peoples Forum on Climate Change (IIPFCC) was explicit about this issue at the Bali climate negotiations in 2007. According to the IIPFCC, REDD programs will not benefit indigenous peoples, but in fact will affect the rights of these communities as a result of the violation of lands rights, territories and resources. 
In this context of global opposition against the REDD initiatives, the Cancun Agreements contained Safeguards in order to clearly state that REDD plus is not only about reducing emissions but halting and reversing forest loss and respect the right of local communities. The Safeguards has been discussed in workshops in order to consult effectively with Parties on biodiversity aspects of REDD-plus, based on relevant decisions of the Convention on Biological Diversity and of the UNFCCC.

The aim has been to cross referencing the safeguard frameworks with processes and guidelines that have already been established. The frameworks are the UN REDD Programme Social and Environmental Principles and Criterias, the FCPF Readiness Fund Common Approach for Environmental and Social Safeguards for Multiple Delivery Partners and The REDD Plus Social and Environmental Safeguards. ${ }^{11}$

The Safeguards are, in words of the Secretariat of the Convention on Biodiversity, essential for the long term success of REDD Plus and to respect the variety of national situations and states of readiness. Nonetheless, the Secretariat recognized that REDD Plus and the Safeguards established are not enough to solve all the relevant governance and biodiversity problems. In this context again, one of the main references is made to the outstanding relevance of clear policies upon the sustainable land use, natural resource use, and land tenure rights. "Impacts on indigenous peoples and local communities, and benefit-sharing are closely linked to solving land tenure and rights issues, including the rights to the forest carbon".

Paragraph 2 of Annex I of the Cancun Agreements contains the following list of Safeguards that must be taking into consideration to implement REDD:

"When undertaking activities referred to in paragraph 70 of this decision, the following safeguards should be promoted and supported:

(a) Actions complement or are consistent with the objectives of national forest programmes and relevant international conventions and agreements;

(b) Transparent and effective national forest governance structures, taking into account national legislation and sovereignty;

11 Submission by the Secretariat of the Convention on Biological Diversity to the Secretariat of the United Nations Framework Convention on Climate Change Document, September 2011, available at http://unfccc. int/resource/docs/2011/smsn/igo/137.pdf. 
(c) Respect for the knowledge and rights of indigenous peoples and members of local communities, by taking into account relevant international obligations, national circumstances and laws, and noting that the United Nations General Assembly has adopted the United Nations Declaration on the Rights of Indigenous Peoples;

(d) The full and effective participation of relevant stakeholders, in particular, indigenous peoples and local communities, in actions referred to in paragraphs 70 and 72 of this decision;

(e) Actions are consistent with the conservation of natural forests and biological diversity, ensuring that actions referred to in paragraph 70 of this decision are not used for the conversion of natural forests, but are instead used to incentivize the protection and conservation of natural forests and their ecosystem services, and to enhance other social and environmental benefits".

Therefore, Safeguards explicitly include active protection to indigenous communities and their participation in the implementation process. In fact, the planning, implementing and financing stages of every REDD program require the full accomplishment of the listed conditions. The Cancun Agreements request that countries prepare an information system to follow up the Safeguards compliance.

Nonetheless, there are a number of non-answered questions related to the fulfilment of those Safeguards, as for example the lack of definitions. While the Cancun Agreements included some activities as part of REDD plus, i.e., reducing emissions from deforestation and forest degradation, conservation and enhancement of forest carbon stocks, and sustainable management of forests - most of these activities are still undefined by the UNFCCC. For example "forest degradation" has not yet been defined; let alone "sustainable management of forests" and "conservation". Without definitions it is not possible to measure progress or pay for performance, which is central to the REDD+ discussions.

Moreover, the application of these conditions is harder than appears due to the absence of enforcement capability of the international organisms, local governments and communities. 


\section{Indigenous Rights and REDD. The Concept of Sui Generis Rights}

Derechos Indígenas y Redd. El concepto de los Derechos sui generis

This article is based on the analysis of some specific indigenous rights and the connection between these rights and the effectiveness of REDD. This section contains the analysis of the sui generis indigenous rights concept resulting from the land tenure and property rights and how the effectiveness of REDD should relies on the recognition and consideration of these rights.

I suggest that the correct perception and structure of indigenous peoples rights over the forests is a key issue for the effectiveness of REDD. The aforementioned, based on the idea to put the right incentives in the right place. In other words, that indigenous peoples, whom historically have been in charge of the sustainable use of the forest, will be the main benefit stakeholders in the implementation of REDD.

\section{(i) The concept of land tenure and natural resources in the context of indigenous communities}

Indigenous peoples have a very deep and special relationship with the land and the environment due to an ancestral, spiritual and cultural background. The use of lands by indigenous peoples is related to the right of self-determination. The Human Rights Committee has affirmed that self-determination for indigenous peoples involves the use and control of traditional lands and resources ${ }^{12}$. In addition, the UN has recognized the spiritual and cultural dimension of the indigenous rights over lands and territories. In this context, the UN acknowledges that the land is more than an economic mean.

One important point to bear in mind is that the indigenous rights arise from customary systems that interact with the legal domestic and international structures. Indigenous rights vary from place to place according the interaction of historical, economic and social factors, and also according to the natural characteristics of the land. In addition,

12 Concluding comments in Canada's fourth periodic report to the Committee, 1999. 
every indigenous community has it owns rules and customary systems. However, they share in most of the cases the following features:

(a) A collective ownership over the lands and natural resources,

(b) Inalienability of lands, based in the concept that indigenous peoples can live off the land for generations and generations,

(c) Historical ownership over the lands, in some of the cases without the legal entitlements recognized by the domestic laws,

(d) Spiritual character of the land, and

(e) The exercise of rights is frequently associated to traditional systems of land tenure and joint use of rights that differ from the national regulations and private law.

As a result, indigenous communities do not perceive natural resources, territories and land in the classic western concept of property, which is focused in an individual notion, whereas the indigenous notion is based on a collective approach.

(ii) Special protection to indigenous communities in the land tenure and natural resources legal framework

\section{(ii.1) Historical perspective}

Indigenous rights over the natural resources and lands have started to being recognized by the national legal frameworks. Nonetheless, since a long time the indigenous communities rights did not have a special protection under the domestic law and were treated in the same way as the private classic rights.

As several authors have recognized, legislation and initiatives to transform communal land into private property have historically constituted a means to expropriate lands for the state and the elite. Indigenous communities have resisted and struggled with the colonization and development of countries, including the extreme exploitation of natural resources within their lands.

Since the adoption of international treaties, -and with the individual effort of some countries-, indigenous law systems started to be recognized and therefore, the indigenous 
rights over the land and natural resources too. The indigenous rights movement gained field in the 1960s and 1970s, when indigenous peoples in the Americas, Australia, New Zealand, and other countries initiated a movement to gain attention to their demands in order to be recognized as special communities with historically based cultures, political institutions, and entitlements to land and also different needs. These movements triggered a number of important international conferences and heightened attention from scholars and international nongovernmental organizations ${ }^{13}$.

Currently, according to the ILO 169 Guide ${ }^{14}$, “(...) many indigenous and tribal peoples have their own customs and practices, which form their customary law. This has evolved through the years, helping to maintain a harmonious society".

"Often, in order to apply these customs and practices, indigenous peoples have their own institutional structures such as judicial and administrative bodies or councils. These bodies have rules and regulations to make sure customary laws are followed. Failure to do so is often punished, and individual lapses often have their own specific punishment.

An effective implementation of internationally recognized indigenous peoples' rights -including land and resource rights, and cultural, social and economic rights- requires that customs, customary law and legal systems of indigenous peoples are recognized and acknowledged, in particular in relation to collective rights of fundamental importance to indigenous peoples" 15 .

\section{(ii.2) International perspective}

One of the most remarkable characteristics of the contemporary international human rights law is the recognition of the indigenous rights. In 1948, the Organization of American States General Assembly included the recognition of indigenous peoples as

\footnotetext{
13 International Law Organization, Indigenous and Tribal Peoples' Rights in Practice. A Guide to ILO Convention number 169, available at http://pro169.org/res/materials/en/general_resources/IPsRightsInPractice-singlepages. pdf.

15 Ibidem.
} 
special subjects of international concern in article 39 of the Inter-American Charter of Social Guarantees ${ }^{16}$.

The International Law Organization Convention No 169 (ILO 169) was set forth in 1989 and since then has been ratified by several states. The convention establishes in it article 2 that: "Governments shall have the responsibility for developing, with the participation of the peoples concerned, coordinated and systematic action to protect the rights of these peoples and to guarantee respect for their integrity".

Regarding the use of natural resources, the ILO 169 requires that "the peoples concerned shall wherever possible participate in the benefits of resource exploitation, and shall receive fair compensation for any damages which they may sustain as a result of such activities". The convention also recognizes the broad concept of territory, including the resources as part of the indigenous rights. Relevant passages of the Convention states that: "The rights of ownership and possession of the peoples concerned over the lands which traditionally occupy shall been recognized (...)".

For the case of participatory rights, which are also tightly connected to the enforcement and exercise of property and use of natural resources rights, the ILO 169 Convention contemplates a consultation process in any case in which the indigenous communities or their rights could be affected. The convention expressly establishes that: "the people concerned shall have the right to decide their own priorities for the process of development as it affects their lives (...). They shall participate in the formulation, implementation and evaluation of plans and programs for national and regional development which may affect them directly" (Article 7).

In addition, the Inter- American Court of Human Rights has ruled, "the international human right to enjoy the benefits of property (...) includes the right of indigenous peoples to the protection of their customary land and resource tenure" (Awas Tingni v. Nicaragua case).

16 Anaya, James and Williams, Robert. The Protection of Indigenous Peoples' Rights over Lands and Natural Resources Under the Inter-American Human Rights System, available at http://www.law.harvard.edu/students/ orgs/hrj/iss14/williams.shtml-Heading80 . 
Moreover, the United Nations Declaration on the Rights of Indigenous Peoples was adopted by the United Nations General Assembly in 2007. The purpose of this Declaration is "to set out the individual and collective rights of indigenous peoples, as well as their rights to culture, identity, language, employment, health, education and other issues. It also emphasizes the rights of indigenous peoples to maintain and strengthen their own institutions, cultures and traditions, and to pursue their development in keeping with their own needs and aspirations"17.

Several international standards have been adopted in concern to the indigenous communities' rights and recognition. The United Nations Human Rights Committee and the Committee on the Elimination of Racial Discrimination are also applicable to protect indigenous peoples' rights and those institutions monitors the fulfilment of this objective.

The Organization of American States is discussing the draft of the American Declaration on the Rights of Indigenous Peoples. In connection with the property rights, the Declaration states the right of indigenous peoples to benefit from economic activities conducted on their lands is an essential element of their right to property. In addition to providing recognition of their rights to control, ownership, use, and enjoyment of lands, the Declaration also provides that indigenous peoples shall participate in the benefits of resource exploitation activities and receive compensation for any loss they may sustain as a result of such activities. This is without any doubt a landmark in the evolution of the recognition of the indigenous rights. However, we should bear in mind that the last word is given by the states and its own domestic laws. As in the case of land tenure, the indigenous rights over use of the resources are not frequently taken into account in practice. The producers have ignored these laws and many communities have entered agreements with forest companies without sustainable basis, which has resulted in the acceleration of the forest degradation.

The United Nations Permanent Forum on Indigenous Issues indicates that in recent decades, many countries have reformed their constitutional and legal systems in response to calls from indigenous movements for legal recognition of their right to the protection and control of their lands, territories and natural resources (as well as with respect to their languages, cultures and identities; their laws and institutions; their forms of government

17 http://www.un.org/esa/socdev/unpfii/documents/FAQsindigenousdeclaration.pdf. 
and more). However, in his March 2007 report, the UN Special Rapporteur on the situation of the human rights and fundamental freedoms of indigenous people, stated that: "Although in recent years many countries have adopted laws recognizing the indigenous communities' collective and inalienable right to ownership of their lands, land-titling procedures have been slow and complex and, in many cases, the titles awarded to the communities are not respected in practice" 18 .

(iii) The concept of sui generis indigenous rights

Sui generis is a Latin expression, literally meaning of its own kind/genus or unique in its characteristics. The expression is often used in analytic philosophy to indicate an idea, an entity, or a reality, which cannot be included in a wider concept. That is in fact what I want to reflect in the paper: that the content of these rights is so special and unique that it is essential for REDD to take them into account in order to assure the success of the program. I have called these special rights as sui generis rights because of it special characteristics derived from the relationship of indigenous peoples with the land and natural resources. Indigenous knowledge entails a deep understanding about the management of natural resources and land. For the indigenous peoples, their rights are part of their cultural heritage and collective experience that often includes a deep understanding of natural resources and therefore this is of a great relevance for environmental conservation and preservation of biodiversity ${ }^{19}$.

The different types of ownership and property rights to define property and the management of natural resources are related to the indigenous know-how, cultural heritage and livelihood necessities.

Although there are a number of sui generis indigenous rights, such as the special intellectual property rights of tribal communities, this paper focuses those sui generis rights related to the land and natural resources in a strict perspective:

18 http://www.un.org/esa/socdev/unpfii/documents/6_session_factsheet1.pdf.

19 Tucker, Catherine M. "Tenure Systems and Indigenous Intellectual Property Rights", Chapter 5. En: Riley, Mary (Ed.). Indigenous Intellectual Property Rights: Legal Obstacles and Innovative Solutions, Rowman Altamira, 2004. 


\section{(iii.1) Right over the territories}

According the international standards, the concept of territory is broader than the concept of land. ILO 169 defines territories in article 13.2: "The use of the term lands in Articles 15 and 16 shall include the concept of territories, which covers the total environment of the areas which the peoples concerned occupy or otherwise use".

Also, the United Nations Declaration on the rights of indigenous peoples recognizes the indigenous rights over the territories as a broader concept. In article 25 of the UN Declaration, the concept of territory is also connected to the spiritual dimension of the protection.

Has the protection of territories suppose, territory is a greater concept that includes the land and resources located within an area occupied ancestrally by a community. Territory also includes the productive function of the land and the environmental services provided by the natural resources. Territory also embraces the cultural heritage and the spiritual connection.

However, closely linked to the land problem in connection with the expulsion indigenous have suffered along immemorial times, is the issue of territory. Indigenous have historically been moved from one place to other but in well-defined geographical areas. Thus, indigenous peoples now are demanding the recognition of these territories as a necessary step to ensure their social, economic, and cultural survival ${ }^{20}$.

\section{(iii.2) Right over natural resources}

As mentioned above, the ILO 169 also recognized the indigenous peoples rights over the natural resources located within the land and territories. Article 15 of the convention states that: " 1 . The rights of the peoples concerned to the natural resources pertaining to their lands shall be specially safeguarded. These rights include the right

20 Stavenhagen, Rodolfo. "Indigenous Peoples: Land, Territory, Autonomy, and Self-Determination” (chapter 11). En: Rosset, Peter M.; Patel, Raj and Courville, Michael (Eds.). Promised Land: Competing Visions of Agrarian Reform, Food First Books, Oakland, California, 2006, pp. 208-217, available at http://www. foodfirst.org/files/bookstore/pdf/promisedland/11.pdf. 
of these peoples to participate in the use, management and conservation of these resources (...)".

The United Nations Permanent Forum on Indigenous Peoples Issues also includes that the majority of the world's remaining natural resources -minerals, freshwater, potential energy sources and more- are found within indigenous peoples' territories. Natural resources have also a broad concept under the indigenous perspective because it includes the forests, water and underground minerals located in their territories. This is one of the most important rights and one of the most conflictive also because a large part of the current and most important right, because many of the current conflicts with indigenous communities are related to the use, possession, control and exploitation of resources within indigenous territories. In fact, several legislations recognized the rights of indigenous over the lands and territories but states remain the owners of natural resources such as water and undergrounds minerals and they grant the exploitation concessions to private parties in order to develop projects (hydropower, timber and mining projects). However, it is necessary to consider that the ILO 169 and the United Nations Declaration on the rights of Indigenous Peoples establish that states shall consult and cooperate in good faith with the indigenous peoples concerned through their own representative institutions in order to obtain their free and informed consent prior to the approval of any project affecting their lands or territories and other resources, particularly in connection with the development, utilization or exploitation of mineral, water or other resources.

\section{(iii.3) Right over environmental services}

Environmental services, also known as ecosystem services are resources, services and processes supplied by natural ecosystems or resources. Collectively, these benefits are known as ecosystem services and include products like clean water and processes such as the decomposition of wastes or carbon sequestration and regulation of the climate. This concept was included in the United Nations millennium Ecosystem Act of 2005. ${ }^{21}$

21 The Millennium Ecosystem Assessment, released in 2005, is an international synthesis by over 1000 of the world's leading biological scientists that analyses the state of the Earth's ecosystem and provides summaries and guidelines for decision-makers. It concludes that human activity is having a significant and escalating impact on the biodiversity of world ecosystems, reducing both their resilience and bio capacity. The report refers to natural systems as humanity's "life-support system", providing essential ecosystem services. 
The payment for environmental services has been one of the means created to protect the services rendered by the ecosystems. One of the most effective ways is to put the management and protection of the ecosystems into the local communities in order to guard and enhance the services provided. Here is where indigenous communities are of the most extreme significance. As mentioned, indigenous communities are the main users of the forests but also are the ones who better known the processes and interactions of those ecosystems.

The payments for environmental services have been understood as a means for reducing poverty in places rich in natural resources. In fact, REDD plus and Safeguards include the concept of reward indigenous communities for maintaining the ecosystems and thus protect the environmental services made by the forests the services they have done to the ecosystem since immemorial times.

As an example, the United Nations Declaration on the Rights of Indigenous Peoples in it article 31st states that: "1. Indigenous peoples have the right to maintain, control, protect and develop their cultural heritage, traditional knowledge and traditional cultural expressions, as well as the manifestations of their sciences, technologies and cultures, including human and genetic resources, seeds, medicines, knowledge of the properties of fauna and flora, oral traditions, literatures, designs, sports and traditional games and visual and performing arts. They also have the right to maintain, control, protect and develop their intellectual property over such cultural heritage, traditional knowledge, and traditional cultural expressions".

Funding for the management of indigenous communities over forests have a wide social benefit. First, because local communities are being favored through the payment for these services and second, because the ecosystems are conserved in a traditional way. However, one of the main obstacles is that most indigenous people have group rather than individual land ownership and hence cannot sell their services as private goods. Here is where REDD implementation should take into account the special features of indigenous rights (mentioned above) in addition with the participatory right of the communities. As the work will conclude, REDD would be not be success if these special characteristics are not taking into account by governments and international community in the implementation of REDD. Forest users are the most prepared communities and 
also have the recognized right to the advantage of these resources producing at the same time a great benefit to the ecosystems and particularly to the prevention of deforestation and forest degradation.

Without considering the special indigenous rights, the sui generis rights, REDD will not be as effective as in the case in which the indigenous communities were the main stakeholders of the program.

(iv) Recognition of sui generis indigenous peoples rights as the key incentive for REDD effectiveness

As I have previously addressed, this research reviews the relationship between the sui generis indigenous rights over the territories, natural resources and environmental services in one hand, and the effectiveness of REDD programs in the other. Whether indigenous peoples and other forests dependent communities are considered the right-holders of these resources, they are going to directly receive the benefits of REDD and the goals prescribed by UNREDD program and it Safeguards would be successfully achieved as consequence.

However, the recognition of indigenous rights must be accompanied with a solid and transparent political and governmental structure that insures the respect of these rights and benefits. Thus, the participatory right is also fundamental for the appropriate REDD implementation.

Most of the legislations and international agreements recognized the land tenure rights of indigenous in the territories in which they have historically been located (however, in practice there are cases in which the rights over the land are not respected and indigenous communities are displaced). The case of the rights over natural resources, including trees, soil, seeds, water, and environmental services as the carbon captured by the tress is more complicated. Despite the fact that domestic legislation and international agreements also recognize the right of indigenous peoples over the resources located in their areas, in practice it is not clear who are entitled over them. 


\section{Interconnection Between Indigenous Rights and REDD}

(i) Relevance of indigenous rights, -including the sui generis rights-, for the success/failure of REDD programs

The rights of the indigenous have been considered as an essential part of the REDD successful. Thus, because REDD is not only about the reduction of carbon emissions through the prevention of deforestation and forest degradation.

One of the key aspects of the REDD successful in connection with the indigenous rights is based on the right allocation of incentives. If the rights are well established and the ownership/management over the resources and environmental services is of the indigenous communities, REDD plus will generate right incentives to incorporate the indigenous within the protection of forests as the mains and most prepared stakeholders. However, these measures must be accompanied with the enhancement of indigenous peoples participation and the correspondent support of Governments and international actors.

According to the vast opinion of experts in this regard, there is clear that any national or international system related to the protection of forests need the knowledge and agreement of forest peoples and local communities. Without this consent, those plans are destined to failure. Previous experiences have shown that this deforestation measures should be implemented from a bottom-up perspective, that is, from forest users that actual live and depend on the forest.

(ii) Effect of these rights under REDD: the bottom-up system

The characteristics of the indigenous rights (customary and collective land tenure systems, communitarian use of natural resources and soft participation rights) could entail that the implementation of REDD would no be so beneficial for local people than it appears.

The realization of REDD programs in developing countries could produce the violation of customary land rights and risk of land conflicts. The legal systems in most of the developing 
forest countries fail to recognize the collective customary rights of indigenous peoples over their ancestral forests, or only recognize a small portion of their traditional lands.

An additional problem that REDD programs could cause is the zoning of protected areas in forests to prevent the logging with the consequent exclusion of indigenous activities within the forests. As consequence, it is very important that States recognize indigenous and local community customary ownership rights over forestlands.

Moreover, the implementation can increase inequality and social conflict. REDD initiatives could generate conflict over boundaries and benefits both within and between rural landholders and forest owners. The huge sums of money that might be involved in the implementation of REDD programs could also create risk of corruption. There is also a risk that benefits will be captured fundamentally by state agencies, local governments and conservation NGOs rather than indigenous peoples and local communities -as has happened in some areas of the pilot avoided deforestation scheme in Noel Kempff National Park in Bolivia. Therefore, other stakeholders receive income, the direct costs of forest protection may disproportionately fall on indigenous and local resource users who may face restrictions on hunting, fishing and shifting cultivation practices as a result of conventional exclusionary protected forest area policies ${ }^{22}$.

Therefore, it is fundamental to apply a bottom-up system in order to create direct incentives to indigenous people. It is essential to respect the customary rights, the collective use of land, the ancestral traditions of people and the involved them in the creation and development of programs. In this sense, the recognition of the so called sui generis rights is very important. The broader concept of lands, meaning territories, the right over the natural resources and the right to the environmental services provided by the forest are very specific and key issues that only the indigenous communities have.

- Thus, the suggested key points regarding a bottom-up system about indigenous issues for the success of REDD plus should be:

22 Griffiths, Tom. Seeing 'RED'? 'Avoided deforestation' and the rights of Indigenous Peoples and local communities. June 2007. Forest Peoples Programme, available at http://www.forestpeoples.org/sites/fpp/files/publication/2010/01/avoideddeforestationredjun07eng_0.pdf. 
- Indigenous rights, including sui generis rights should be recognized in theory and in practice at the international and domestic level.

- In addition, these rights should be enforceable.

- Indigenous and local peoples should be directly engaged in the current international and national debates on REDD policies and national mechanisms and approaches based on the implementation of REDD

- The free, prior and informed consent, the respect for customary land and resource rights, the land tenure security and equitable benefit sharing and good governance rights of indigenous communities must be protected

- Indigenous peoples should maintain, retain and recover control over their forests and receive support from the government and international community.

- The opinion of indigenous communities must be taken into consideration in order to define guarantees; mechanisms of implementation, protection systems and other stakeholders involve in future projects.

- The activities implemented must be compatible with the traditional ways of life and social organization of indigenous and also they have to contribute to ensuring the sustainability of the natural resources.

From this evaluation, REDD can improve the State role to securing indigenous people's exclusion rights over their territories, ensuring the commitments are met in addition to enhance the protection of the forests from the degradation.

Finally, an additional main effect of these rights under REDD will probably be the new value allocated to the forests under the figure of environmental services, such as the capture of carbon made by trees. However, REDD can be the gateway to this new kind of services.

\section{Conclusions}

The recognition of indigenous rights over the territories, natural resources and environmental services is one of the key aspect of the REDD plus success because the well-established rights will create incentives for indigenous communities to get more involved in the initiatives and to enhance the protection of the forest and, in addition, 
to achieve the final goal of REDD which is reducing emissions from deforestation and forest degradation. Nonetheless, to conclude this objective it is also fundamental the commitment of the States in relation to the participation of indigenous communities.

However, in most of developing countries, the implementation of REDD plus need to pass through a long way before legal structures and government competences are ready to affront the concrete application of these programs.

Progresses have been made but are not enough yet. In general, the uncertainty about who will be benefit from the REDD carbon markets could create the potential for tenure conflict. And even in places in which the property right are more or less clear, the implementation of REDD programs could activate new pressures on land tenure and resources governance.

The land tenure systems and the rights over the territories are marked by the use of collective soils and the lack of registered titles. The states in some way recognize the domain over the lands and over the resources within them, but in the other hand, states have the faculty to grant concessions in those areas. Therefore, in many cases there is a superposition of domains. In addition, the lack of secure tenure for local population is one of the main causes of deforestation in developing countries.

In connection with the use of natural resources, domestic legislations give the right over the resources exclusively to the indigenous communities. However, because of a number of external factors, the legislation is not being implemented and there is increase deforestation in the areas in which local communities live.

The implementation of REDD plus programs could improve the recognition of the indigenous peoples land tenure and resources-use rights. The question is how. One possible way is formalizing the property rights of people in a special registration system, but these seem to be impracticable in most of the developing countries due to the lack of resources and institutional preparation.

The other likely (and more feasible) way is to respect the land tenure, natural resources use and environmental services rights of indigenous people in the forests. For that, it is necessary to make them part of the programs (bottom-up perspective), improve and 
enhance their participatory rights and have strong and efficient government with the commitment to do so.

However, securing tenure, territories, environmental services and resources rights alone will not ensure that stakeholders will be able to participate in decision-making process. As I have pointed out, the participatory rights are extremely important too. Nonetheless, the role of consultation and consent has been one of the most conflictive things in the REDD negotiations.

At this point, most of developing countries in which the REDD and REDD plus programs could be implemented have almost the same concerns. The solutions to these concerns are in summary the following:

- As the implementation activities will occur within a variety of property rights systems that co-exist and overlap within countries (from formal and private property rights to customary ones), the operation of REDD plus programs should consider every special system and protect the land tenure rights (or factual situations).

- Clear definition of stakeholders, tenure and territory rights, natural resources rights and environmental services rights is necessary to enhance de REDD plus

- Get involved indigenous communities in the whole implementation process. Enhance and improve their participatory rights and implement a bottom-up process.

- Political will. REDD should not be a mechanism for forest's management centralization.

- REDD plus seeks to establish national legal frameworks, respecting the customary systems of indigenous peoples.

- Monitoring, reporting and verification systems created taking into consideration the specific characteristics of each country.

- Effective local governance institutions whit enforcement capability

- To create effective incentives for protecting forests, action to strength resource tenure must be combined with policy interventions. Tenure is only one part of the eventual social problems derived from the REDD scheme.

As conclusion, the effectiveness of REDD plus depends on the full respect of indigenous rights, including those more specific that I have called sui generis rights, as the main experts 
in the forests. Thus, as a virtuous circle, the indigenous will be also beneficiated from the REDD plus experience. This, due to the equitable shares of benefits, the protection of forests, and the sustainable use of their habitats the improvement of their participatory rights and the strength of the government structures. 
